\title{
The Benefits of Voting Trust System in the Current Corporate Governance of China
}

\author{
Ali Raza Ansari* Alexandra Jane Davis \\ Guanghua Law School, Zhejiang University, Postal code 310000, Hangzhou, China
}

\begin{abstract}
The inclusion of a shareholder voting trust system in China is an important, yet absent, feature of modern corporate sector. Despite its necessity, it seems that no proper notice of its nonexistence has been taken in the past nor has any attention been paid to this particular area in previous decades. Since China lies among the top corporate players of the world, there is a need for increased trust from the general public to invest in the current corporate sector. It is the position of this paper that the most practicable way of achieving this goal is to introduce a shareholder voting trust system. Therefore, this paper shall focus on all the advantages that voting trust systems have provided in the corporate world and how similar systems could potentially be introduced into the Chinese corporate system.
\end{abstract}

Keywords: Voting Trust, Minority Shareholders Protection, Corporate Governance,

DOI: $10.7176 / \mathrm{JLPG} / 104-07$

Publication date: December $31^{\text {st }} 2020$

\section{Introduction}

A shareholder voting trust is a device which is used to transfer voting rights from one person to another. The other person, known as a trustee, can thereby attend shareholders' meetings and becomes eligible to vote in relation to the trust which has created through execution of an agreement with two or more shareholders. ${ }^{1}$ The voting trust system is very necessary for the purpose of securing confidence of shareholders in the corporation. The main and foremost reason for the adoption of a voting trust agreement is the ease through which shareholders can resolve their issues - just by transferring their shares to a blind trustee, the probability of avoiding confrontation increases. At the same time, a voting trust can also benefit a corporation through its use to prevent any hostile take-over maneuvers. Hence, whenever the shareholders sense the smell of invasion, the shareholders could band together to create a block through which the possibility of such takeover could be curtailed. ${ }^{2}$

Additionally, voting trusts help coax an otherwise timid general public in participating in investment economy. The fiduciary duty of a trustee to a shareholder and standards in place for the execution of a voting trust agreement help bolster faith in corporate governance and allow for even unsophisticated investors to feel that they are in good hands. ${ }^{3}$ Whenever, the voting trust is created in the corporation the trustee is obligated to present a voting trust certificate to the shareholders in return for an assurance that it has shifted the control of his/her shares in favor of the trustee who shall then on execute powers on his/her behalf in the corporation until the trust agreement expires. ${ }^{4}$ Similarly, the voting trust is beneficial whenever the company is going through the process of reorganization due to the reason of financial crises in such scenario the shareholders could also transfer their shares in favor of the trustee who could take several actions on their behalf. Likewise, such transfer also assists the company in regaining its lost financial momentum. On the other hand, the voting trust system could also be used as a helpful device under those conditions where shares are transferred inside the family. Especially in those cases where parents opt to transfer shares in favor of a child, the use of a trustee to vote on behalf of the minor can protect the child's interests from any probable intrusion and without requiring the impractical participation of said child in shareholder voting. ${ }^{5}$ This whole discussion clearly illustrates the extraordinary importance of the voting trust agreement and the protection voting trusts provide to shareholder rights.

\subsection{Historical Background of voting trust}

The voting trust was initially adopted by the USA and this gave birth to the first ever statue of voting trust which was embraced by the New York state in 1901. within the span of next seven years it was then espoused by the state of Maryland in 1908. After the gap of almost seventeen years the state of California emerged as the third state to

\footnotetext{
${ }^{1}$ See J. Gordon Gose, "Legal Characteristics and Consequences of Voting Trusts", 20:3 WASH. L. REV. 129, 129 (1945).

2 See "What is a Voting Trust", Corporate Finance Institute, (2015) available at https://corporatefinanceinstitute.com/resources/knowledge/deals/voting-trust/.

${ }^{3}$ See Dalia Tsuk Mitchell, "Shareholders as Proxies: The Contours of Shareholder Democracy", 63 WASH. \& LEE L. REV. 1503, 1526-28 (2006) (noting that individual shareholders lost confidence in the system when there was no mechanism by which a small investor could have a 'meaningful voice' in a corporation); see also John W. Giles, "Is the Voting Trust Agreement a "Dangerous Instrumentality"?", 3 CATH. U. L. REV. 81, 85 (1953) (quoting Coleman Burke and his favorable views on voting trusts for the reason that they are "normally beneficial to all concerned").

${ }^{4}$ See Gose, supra n. 1 at 138.

${ }^{5}$ Corporate Finance Institute, supra n. 2.
} 
adopt voting trust in $1919 .{ }^{1}$ Initially, its usage was kept quite restricted in the state of California and it's usage was only allowed to the corporations for the purpose of marketing of agricultural products. However, within following years this system was embraced by several new states such as : Delaware, Florida, Nevada, Ohio, Arkansans, New Jersey and Louisiana. ${ }^{2}$ With that being the case slowly and gradually this newly introduced system was adopted by numerous other states one after another. However, when we go back in the pages of history then it could be observed that primarily, there were five main historical statues from which this whole system has been evolved over the past century ${ }^{3}$. which includes: New York, Delaware, and Ohio. Initially, those were the three main states which introduced voting trusts into the corporate world besides two other model acts. ${ }^{4}$ Likewise, There are several other corporate systems in the world which have prospered because of the voting trust system or due to a similar kind of body with a different name. For instance, in the corporate governance of France there is a system called "Syndicats-de-Blocage" under which the voting rights are transferred to the heads of syndicates/organizations who act and vote on behalf of all the shareholders. ${ }^{5}$ In the meantime this system is flourishing in some other European countries like Italy where this system has been propelling over the years and it has provided a way for both the shareholders and management to protect themselves from any unwarranted incidents like take over and other aggressive maneuver's towards corporation. It was discovered that, the one third of the major business in the Italian listed companies has been run by the large number of shareholders jointly through "Patti di Sindacato" which is the Italian term for voting trust and not only that these agreements were made public through national newspaper which publishes all the details of such agreements including the term of expiry which were also transmitted to the (Italian security and exchange authority). ${ }^{6}$ The evidences further suggest that voting trust has contributed in increasing the efficiency of governance there are significant proofs which reflects how it has increased the executive benefits and firm value in the Italian corporations. If for instance the firms faced with $10 \%$ decline in the profit's, then the executive income probably surges up to $7 \%$ if the same was being controlled through the voting trust system. On the contrary, it also suggests that the firm value is likely to be ranged between 14 to 40 percent when the firm is controlled through the voting trust. ${ }^{7}$ Moreover, many other countries - such as Canada and the Philippines ${ }^{8}$ - have also acknowledged the legitimacy of shareholder voting trusts by allowing for shareholder trust agreements. Similarly, finally, Japan has also implemented a voting trust system that triggers specifically in hostile takeover situations. ${ }^{9}$

\subsection{The benefits of voting trust agreement}

The voting trust is an instrument through which control of a corporation can be devised. For a better understanding, we can say that the voting trust entails the trustee with power to exercise the legal right as owner of shares through a voting trust agreement and in return, the shareholders becomes legally entitled to receive benefits such as dividends as beneficial owner. ${ }^{10}$ Likewise, the voting trust agreement is as much beneficial for the companies as it is for shareholders. Specifically, in situations where the company is going through the business expansion process and it invites new investors, the company's major holders normally offer a voting trust agreement so that the interest of newly entered investors can be safeguarded as the entirety of voting rights are transferred into the hands of an impartial trustee. ${ }^{11}$ This type of agreement is equally beneficial for both the majority and minority shareholders because while this device secures the interest of majority shareholders from each other, it naturally protects the interest of minority shareholders from the majority shareholders simultaneously. Therefore, the ultimate goal of company - which is normally to make business decisions that result in huge profits - is easily achieved through the help of voting trust. ${ }^{12}$ Furthermore, voting trust agreements are also profitable for creditors as the agreements help the creditors to secure their interest when a corporation is not doing well, specifically, under circumstances when it appears obvious that the company is on the verge of becoming insolvent. ${ }^{13}$ Under those

\footnotetext{
1 See Thomas W Watkins, "The Development of Voting Trust Legislation", 35 U. DET. L. J. 595, 600 (1958) available at https://heinonline.org/HOL/LandingPage?handle=hein.journals/udetmr35\&div=45\&id=\&page=.

${ }^{2}$ Ibid.

${ }^{3}$ See Id. (citing California is the only state whose statute cannot be traced to some other model. See CAL. COP. CODE $\$ \S 2230-31$ (1955).

${ }^{4}$ See Id. (citing The text of these laws and models appears in Appendices A-1 to A-5.

${ }^{5}$ See Carl Martin Ross, "Comparative Note on Shareholders Voting Agreement", 15 SCANDINAVIAN STUDIES IN LAW, 163-190 (1971) available at https://heinonline.org/HOL/Page?handle=hein.intyb/svns10015\&id=163\&collection=intyb\&index=.

${ }^{6}$ See Gianfranco Gianfrate What Do Shareholders Coalition Really Want? Evidence From Italian Voting Trusts (2007) Corporate Governance An: International Review V.15 Iss.2 pp.122-132 available at https://onlinelibrary.wiley.com/doi/full/10.1111/j.1467-8683.2007.00549.x.

${ }^{7}$ See ibid (citing Volpin (2002).

${ }^{8}$ See Section 59 of the Corporation Code of The Philippines provides for the establishment of a voting trust agreement not exceeding five years duration.

9 See "Trust-Type Rights Plan", Trust Companies Association of Japan (2020) available at https://www.shintakukyokai.or.jp/en/trusts/trusts03_14_10.html.

${ }_{10}$ See Maurice Finkelstein, Voting Trust $\quad$ Agreements, 24 MicH. L. REV. $344 \quad$ (1926) available https://heinonline.org/HOL/Page?collection=journals\&handle=hein.journals/mlr24\&id=373\&men_tab=srchresults\#

${ }^{11} \mathrm{Ibid}$.

${ }^{12}$ Ibid.

${ }^{13}$ Ibid.
} 
situations the creditors often use the voting trust agreement to re-establish the business of the company. ${ }^{1}$ Hence, under such conditions what the voting trust does is it provides a way for the trustees to "block the stock" and in some occasions it gives the entire control of the corporation to the trustees in return for the trustees provision of sound management resulting in long term benefits for the whole corporation. ${ }^{2}$ There are scores of cases in the past where courts are found praising this new, more efficient management for the corporation. ${ }^{3}$ Therefore, due to the existence of the voting trust, the company's shareholders and other related entities are fully assured that their stake is in the safe hands of competent management which will take good care of their corporation - and investment and simultaneously, a safer way for creditors to lend money to the corporation is also provided. Thus, the voting trust agreement is an important device for raising funds, buying property, and for achieving other important developments for the corporation. A similar kind of voting trust was executed between the Trans World Airlines and Hughes Tool Company in United States under which the Hughes Tool Company supported the financing of Trans World Airlines by allowing the board seats to the creditors. ${ }^{4}$ Under this accord, the stock of Trans World Airlines was held by the Hughes Tool Company and the same was put under the hands of three different trustees, two trustees belonged to Trans World Airlines and one belonged to Hughes Tool Company. ${ }^{5}$ The whole agreement was based on the condition that the Hughes Tool Company would provide money to the Trans World Airlines so that they could buy new Aeroplan's. ${ }^{6}$ Thus, Trans World Airlines benefitted from the voting trust agreement by gaining capital to expand their business, the shareholders benefitted from the new revenue being brought in by such expansion, and the creditors benefitted from expedited return on money lent. ${ }^{7}$ Besides those mentioned benefits, there are some other benefits of voting trust agreements which other agreements like pooling and proxies lack since they normally require judicial implementation.Voting trust agreements do not necessarily require judicial implementation; Likewise, the father of voting trust device, an esteemed Professor Henry Winthrop Ballantine, once said that, the voting trust authorizes the trustee to act as an owner himself which is rather different than an agent who merely acts under the command of his principal. ${ }^{8}$ Similarly, a voting trust agreement can be used when the corporation feels that it should wind up its business. The case of Clowes $v$. Millers is a perfect example of this kind of voting trust agreement. ${ }^{9}$ In this case, the voting trust was created for the purpose of selling stock. ${ }^{10}$ Likewise, in 1919, the court of New Jersey endorsed a voting trust where it was established to prevent the submarine producing corporation - which was building submarines for the English government - from getting into the hands of German spies. ${ }^{11}$ Hence, it would not be wrong to say that voting trust emerged as a device meant to maintain corporate control and has historically benefitted corporations from unwanted takeover. ${ }^{12}$

\subsection{Voting trusts importance for the entire corporate sector}

One of the many benefits voting trusts give to corporations and the corporate sector is its ability to curb corporate difficulties such as shareholder activism. Shareholder activism has caused many concerns in the corporate sector through the creation of conflicts between management resulting in a change in dynamics of the corporations and its strategies. ${ }^{13}$ Shareholder activism has also affected the normal cycle of corporate governance ${ }^{14}$ and has raised many issues including political, social, and environmental ${ }^{15}$ This atmosphere has driven the whole corporate market towards the pure political system rather than a market-based environment. ${ }^{16}$ It has further been claimed that shareholder activism has taken the entire command of corporations into its hands and the activists are the ones who actually direct the corporations in making important decisions. ${ }^{17}$ Therefore, it has disrupted the natural

\footnotetext{
${ }^{1}$ Ibid.

${ }^{2}$ Ibid.

3 See "The Voting Trust: Drafting Suggestions", 42 N.Y.U. L. REV. $349 \quad$ (1967) available at https://heinonline.org/HOL/Page?collection=journals\&handle=hein.journals/nylr42\&id=380\&men_tab=srchresults.

${ }^{4}$ Ibid.

${ }^{5}$ Ibid.

${ }^{6} \mathrm{Ibid}$.

${ }^{7}$ Ibid.

8 See John J. Woloszyn, "A Practical Guide to Voting Trusts," U. OF BAltimore L. ReV.: Vol. 4: Iss. 2, Article 4 (1975) available at: http://scholarworks.law.ubalt.edu/ublr/vol4/iss $2 / 4$.

9 See Louie M. Horne, Voting Trust Agreements in Indiana, 19 IND. L.J. 225, $226 \quad$ (1944) available at https://heinonline.org/HOL/Page?collection=journals\&handle=hein.journals/indana19\&id=236\&men_tab=srchresults\# (citing 60 N.J.Eq. 79, 47 Atl. 345 (1900)

${ }^{10}$ Ibid.

11 Ibid (citing Frost v. Carse, 91 N.J.Eq. 124, 108 Atl. 642 (1919).

${ }^{12}$ See ibid; Turner Vann Adams, “Corporations -- Voting Trusts -- Should Trust Principles Apply to Close Corporations?”, 48 N.C. L. REV. 336, 344 (1970).

${ }^{13}$ See Maria Goranova, Lori Verstegen Ryan Shareholder Activism: A Multidisciplinary Review Journal of Management 2013 available at http://jom.sagepub.com/content/early/2013/12/13/0149206313515519 (citing (David, Bloom, \& Hillman, 2007; David, Hitt, \& Gimeno, 2001, Song \& Szewczyk, 2003; Westphal \& Bednar, 2008).

${ }^{14}$ See ibid (citing (Davis \& Thompson, 1994; Dimitrov \& Jain, 2011).

${ }^{15}$ See ibid (citing (Clark \& Crawford, 2012; David et al., 2007; Reid \& Toffel, 2009).

${ }^{16}$ See ibid (citing (Karpoff, Malatesta, \& Walkling, 1996; Wahal, 1996).

${ }^{17}$ See ibid (citing Duhigg, 2007: C1)
} 
balance of power in today's modern corporate world. ${ }^{1}$ Shareholder activism has been often termed a controversial element of the corporate system as on number of occasions it has caused ambiguity and misguidance as to the actual desires of the targeted corporations which ultimately turns into their eventual total ineffectiveness. ${ }^{2}$ Likewise, major shareholders often use several types of activism - for example, exit activism, also known as the "Wall Street walk", a kind of activism under which the majority shareholders threatens the firm to sell shares - for personal gains such as modeling a company's direction towards an avenue most attractive or profitable to them. ${ }^{3}$ Due to this very reason, majority shareholders are often found pressurizing corporate management because of a result of their influence over the top management and other stakeholders; whenever the majority shareholder feels that corporate direction is going against their will, they can execute the threat of selling shares and walking out of the company. ${ }^{4}$ It is true that, being an active shareholder is good but being an activist could turn out very badly especially when activism disrupts the direction of the whole company. It would not be wrong to say that shareholder activism is simply a device for power hungry players who intends to oust other shareholders' interest. ${ }^{5}$ In today's world, shareholder activism is exercised through hedge funds which point out weaker areas of company management and after they establish a large stake in the corporation, they put pressure on the management and dictate their decisions according to their will. However, under such circumstances voting trust could also be used as an important device to overcome the issue of activism as it provides an avenue for shareholders to band together. Under such circumstances, any aggressive act or pressuring tactic on part of a majority activist shareholder could be "blocked" right away by the rest of the shareholders coming together. ${ }^{6}$ Thus, it is clear that, every corporation should include some form of protective system like a voting trust agreement in its corporate sector through which issues like activism and other problems of like nature could be curbed. ${ }^{7}$

\section{Introduction of voting trust in China in accordance with the essence of Chinese characteristics}

Just like the law of nature ${ }^{8}$ it is important that before introducing any new system it should be kept in mind that the present characteristics of the law should be maintained at any cost. Similarly, while suggesting the introduction of this new system in China, it is necessary to keep in mind that it should not affect the very essence of the law, meaning the characteristics of the law. ${ }^{9}$ The main characteristics of the Chinese corporate law is derived from the Company Law of China which was initially promulgated in $1993 .{ }^{10}$ Whereby, under Article 1 of the Company Law, the main emphasis is focused on the flourishment of the socialist economic system with law demonstrating "Chinese characteristics." Besides the organization of the company, further concentration has centered on the idea of protecting the rights of all other entities related to the company. ${ }^{11}$ By looking at the essence of the socialist system, it appears that the introduction of a voting trust system/agreement would provide a positive outcome for the whole of China.

The Chinese characteristics referenced in Article 1 are based in strictly Eastern values untouched by Western legal tradition - that of ancient history, Confucianism, and the importance of administrative authority. ${ }^{12}$ As part of China's socialist past and present, the legal doctrine of China is that "legal rules represent the will of the people."13 Furthermore, the law in China has an aim of creating a harmonious society with an eye towards coordinated and sustainable development. ${ }^{14}$ Therefore, the law must comport with the "Chinese characteristics" of their socialist law system, or better put "a civil law system governed by socialist ideology with Confucian ethos representing Chinese tradition." 15 A law allowing for voting trusts or the adoption of a standard voting trust agreement does just that. As discussed throughout this paper, voting trusts preserve minority shareholder rights and prevent

\footnotetext{
${ }^{1}$ See ibid (citing Davis \& Thompson, 1994; Kahan \& Rock, 2010).

${ }^{2}$ See Marco Becht, Julian Franks, Colin Mayer, Stefano Rossi, "Returns to Shareholder Activism Evidence from a Clinical Study of the Hermes U.K. Focus Fund" (2007) available at https://www.academia.edu/people/search?utf8=\%E2\%9C\%93\&q=shareholder+activism+disadvantage. ${ }^{3}$ See Janet H. Marler, Christophe Faugère, "Shareholder Activism and Middle Management Equity Incentives", Corporate Governance: An International Review, 2010, 18(4): 313-328 (citing Ryan \& Schneider, 2002; Parrino et al., 2003).

${ }^{4}$ See ibid.

See Donald Nordberg, "Some Are More Equal: The Politics of Shareholder Activism" (2009) available at http://dx.doi.org/10.2139/ssrn.1150130

${ }^{6}$ See supra n.2.

${ }^{7}$ See ibid.

${ }^{8}$ See Gerald R. Thompson, Chapter 3: The Characteristics of Law, Legal Foundations: The Framework of Law, LONANG INSTITUTE (2010) available at https://lonang.com/commentaries/foundation/framework-of-law/text/the-characteristics-of-law/.

${ }^{9}$ See Dr. Zhao Ying, "A Brief Guide to The Legal System of China”, DAILY FT (June 21, 2018) available at http://www.ft.lk/columns/A-briefguide-to-the-legal-system-of-China/4-657550.

${ }^{10}$ See https://www.jus.uio.no/lm/china.company.law.1993/.

${ }^{11}$ See ibid.

${ }^{12}$ See Ignazio Castellucci, "Rule of Law with Chinese Characteristics," Annual Survey of Int'l \& Comp. L.: Vol. 13, Iss. 1, Article 4, p. 38

(2007), available at http://digitalcommons.law.ggu.edu/annlsurvey/vol13/iss1/4.

${ }^{13}$ Ibid at 46.

${ }^{14}$ See Mo Zhang, "The Socialist Legal System with Chinese Characteristics: China's Discourse for the Rule of Law and Bitter Experience", 24.1 TEMPLE INT’L \& COMP. L. J. 1, 44 (2010)

${ }^{15}$ Ibid at 48 .
} 
shareholder activism, thus, protecting individuals - or the will of the people - and promoting harmony within the corporate sector. ${ }^{1}$ Moreover, voting trusts have proven their worth in several different countries in the past and there is no proof that this system has ever interfered with the actual characteristics of any law of the respective countries. ${ }^{2}$ However, what it has done is it has provided assistance to the already existing system. Therefore, its adoption could be helpful in achieving the goals for shareholders set by the Company Law of China. Under Article 4, of company Law it is provided that, shareholders shall enjoy all privileges - such as huge profits earned through capital transactions - and shall also be authorized to take part in making important decisions in the company such as electing managers - and he/she shall also be allowed to enjoy other rights which the law provides in accordance with the provisions of the Company Law. ${ }^{3}$ A voting trust system creates a pathway for all shareholders to meaningfully participate in the governance of a corporation and therefore provides an avenue of fulfillment under Article 4.

2.1. Voting trust an ideal mechanism for increasing the minority shareholders confidence in corporations. The voting trust system is a productive way of increasing the confidence of minority shareholders in the corporation. Minority shareholders can use this device to keep a check and balance on the management whenever they feel that the management is going down a path that only benefits themselves (or some pressuring majority shareholder). ${ }^{4}$ Under such circumstances, if the same is left unchecked, then the actions of management could have a severe impact on minority shareholder interest. ${ }^{5}$ However, minority shareholders can use a voting trust agreement to extract other minority voters from the market through which they can prevent the assembly of an insurmountable pack of majority shareholder and keep an eye/maintain a modicum of control over corporate management. ${ }^{6}$ Hence, for that very reason, courts have upheld the need of voting trust agreements for protection of minority shareholders by permitting unification of their voting power into one. ${ }^{7}$ Specifically, in closely held corporations voting trusts are important as they provide - and sometimes the only - platform for minority shareholders to be heard by corporate management. ${ }^{8}$ Many scholars, such as Lucian Bebchuk - professor at Harvard Law School - , suggest that increasing the control of minority shareholders in making important corporate decisions will assist the entire corporation in countering management agency issues and it, thereby, naturally increases shareholder value. ${ }^{9}$ However, for turning this theory into a possibility, there is only one way to go which is establishing a voting trust system in China. ${ }^{10}$

\subsection{Important Platforms for Shareholders protection in China}

In today's modern world much attention is being paid towards the subject of securing the interest of minority shareholders. ${ }^{11}$ The recent developments in the Chinese corporate sector demonstrate the same story as in today's China much attention is being paid to this subject. The Supreme People's Court has recently issued several provisions for the protection of minority shareholders through which they could prevent themselves from numerous unwarranted actions committed by majority shareholders. ${ }^{12}$ The Supreme People's Court has pointed out five different areas where action is required to be taken so that minority shareholders could be protected from

\footnotetext{
1 See Milton M. Bergerman, "Voting Trust and Non-Voting Stock" YALE L. J. 445 , 454 available at https://igitalcommons.law.yale.edu/cgi/viewcontent.cgi?referer=\&httpsredir=1\&article=3268\&context=ylj.

${ }^{2}$ See Carl Martin Ross, supra n.10.

See Company Law of the People's Republic of China (2018 Revision) available at http://www.ghiplegal.com/static/frontend/img/pdf/company_law_en.pdf.

${ }^{4}$ See Gary D. Burger, "The Voting Trust: California Effects A Barrier To A Rationale Law of A Corporate Control”, STANFORD L. REV. 18(6) 1210, 1210-1220 (1966) available

https:/www.jstor.org/stable/1227129?Search=yes\&resultItemClick=true\&searchText=voting\&searchText=trust\&searchText=impact\&search $\mathrm{Text}=$ on\&search Text $=$ minority\&search Text $=$ shareholder\&searchUri $=\% 2 \mathrm{Faction} \% 2 \mathrm{FdoBasicSearch} \% 3 \mathrm{FQuery} \% 3 \mathrm{Dvoting} \% 2 \mathrm{Btrust} \% 2 \mathrm{Bimp}$ act $\% 2$ Bon $\% 2$ Bminority $\% 2$ Bshareholder $\% 26 \mathrm{amp} \% 3 \mathrm{Bfilter} \% 3 \mathrm{D} \& \mathrm{ab}$ segments $=0 \% 2 \mathrm{Fl} 2 \mathrm{~b} \_100 \mathrm{k} \_$with tbsub $\% 2 \mathrm{Fcontrol} \&$ seq $=1 \#$ metadata $\mathrm{i}$ nfo_tab_contents.

${ }^{5}$ Ibid.

${ }^{6}$ Ibid.

${ }^{7}$ Ibid.

${ }^{8}$ See ibid.

${ }^{9}$ See Zhihong Chang, Bin Ke, Zhifeng Yang, "Minority Shareholders Control Right and The Quality of Corporate Decisions In The Weak Investor Protection Countries: A Natural Experiment From China," THE AcCounTING ReV., Vol .88, No. 4, 1211, 1212 (2013) available at https://www.jstor.org/stable/23525976?Search=yes\&resultItemClick=true\&searchText=voting\&searchText=trust\&searchText=impact\&searc $\mathrm{hText}=$ on\&search Text $=$ minority\&searchText $=$ shareholder\&searchUri $=\% 2 \mathrm{Faction} \% 2 \mathrm{FdoBasicSearch} \% 3 \mathrm{FQuery} \% 3 \mathrm{Dvoting} \% 2 \mathrm{Btrust} \% 2 \mathrm{Bim}$ pact $\% 2 \mathrm{Bon} \% 2 \mathrm{Bminority} \% 2 \mathrm{Bshareholder} \% 26 \mathrm{amp} \% 3 \mathrm{Bfilter} \% 3 \mathrm{D} \& \mathrm{ab}$ segments $=0 \% 2 \mathrm{Fl} 2 \mathrm{~b}$ _ $100 \mathrm{k}$ _with tbsub $\% 2 \mathrm{Fcontrol} \& \mathrm{refreqid}=$ search $\%$ 3A934ab6be73acdca2113362401de0d9c8\&seq=1\#metadata_info_tab_contents.

10 See generally, ibid.

${ }^{11}$ For example, the UK Companies Act provides protection for minority shareholders, as well as laws in other parts of Europe, Japan, and India. See Section 994 of the Companies Act 2006 (United Kingdom); IOSCO, "Protection of Minority Shareholders in Listed Issuers" (June 2009) available at https://www.iosco.org/library/pubdocs/pdf/IOSCOPD295.pdf; Sections 397 to 409 of the Companies Act of India 1956 (Companies Act).

12 See Shan Yuxiao, Denise Jia, "Supreme Court Move to Protect Minority Holders Rights" (2019) available at https:/www.caixinglobal.com/2019-04-30/supreme-court-moves-to-protect-minority-holder-rights-101410188.html.
} 
acts of aggression. These areas have been identified as follows: (1) Damages inflicted through party-related transactions - this kind of situation normally arises when majority shareholders drive the whole corporation according to their will and force the corporation to take actions which may not be fruitful for the corporation or any of the minority shareholders. This action is also contrary to Article 21 of the Company Law. Likewise, Article 84 of PRC General Rules for the Civil Law provides that the controlling shareholders or any person holding such status shall not be allowed to effect the interest of any legal entity connected to the company by using any party related transactions. ${ }^{1}$ (2) Directors removal without any plausible reason - if the director has been removed from office without plausible ground, he shall be entitled to bring suit to void the removal and he shall be eligible to claim such indemnification deemed reasonable by the court. ${ }^{2}$ (3) Limitation of time for profit distribution to shareholders - according to Article 14 and 15 of Supreme People's Court 2017 Provisions, the shareholders are entitled to receive profits through resolutions accepted at shareholders meetings. If the shareholder feels that his due share has not been given to him, then he shall have the right to sue and shall take the matter before a court of law and the court shall, after complying with all the legalities, grant relief in favor of shareholder who is so aggrieved. ${ }^{3}$ (4) Dispute settlement issues among shareholders - the Supreme Court's $5^{\text {th }}$ Interpretation emphasizes on the mediation platform whenever there is a dispute between shareholders. Alternative resolution includes buying of equity by the company from shareholders, equity transfer by one shareholder to other shareholders, shareholders transferring their equity to third parties, reduction of capital by the company, company split, or any other way through which the dispute could be resolved so that the dissolution could be prevented. ${ }^{4}(5)$ The application of these provisions - the judicial interpretation of this provision is of significant importance as it is binding upon all the courts of China. Moreover, Article 6 of the provision states that the same could be applied to those cases where final judgement is still pending. ${ }^{5}$

\section{Conclusion}

It is obvious that Chinas growth pace is such that no other country has ever witnessed in the past. Therefore, it is imperative for the further betterment of its corporate sector that it should include the missing objects for corporations to flourish at a steady pace. Hence, the inclusion of a voting trust system could be an important device to provide better opportunities for small shareholders which ultimately benefits the entire corporate system of the country in general. ${ }^{6}$ Therefore, if a voting trust system is adopted into the corporate system then it would also assist in overcoming extra privilege factors from corporations which normally lay with the majority shareholders. Thereby, there will be a balance in the corporate sector. Simultaneously, minority shareholders would be able to make a block to prevent corporations from harmful incidents. Thus, such a system could emerge as an ideal resolution for Chinese corporate governance as it helps dilemmas that normally incur on all sides in corporations.

\section{References}

${ }^{1}$ See J. Gordon Gose, "Legal Characteristics and Consequences of Voting Trusts", 20:3 WASH. L. REV. 129, 129 (1945).

1 See "What is a Voting Trust", Corporate Finance Institute, (2015) available at https://corporatefinanceinstitute.com/resources/knowledge/deals/voting-trust/.

${ }^{1}$ See Dalia Tsuk Mitchell, "Shareholders as Proxies: The Contours of Shareholder Democracy”, 63 WASH. \& LEE L. REV. 1503, 1526-28 (2006) (noting that individual shareholders lost confidence in the system when there was no mechanism by which a small investor could have a 'meaningful voice' in a corporation); see also John W. Giles, "Is the Voting Trust Agreement a "Dangerous Instrumentality"?”, 3 CATH. U. L. REV. 81, 85 (1953) (quoting Coleman Burke and his favorable views on voting trusts for the reason that they are "normally beneficial to all concerned").

${ }^{1}$ See Gose, supra n.1 at 138.

${ }^{1}$ Corporate Finance Institute, supra ${ }^{7}$ n. 2.

${ }^{1}$ See Thomas W Watkins, "The Development of Voting Trust Legislation", 35 U. DET. L. J. 595, 600 (1958) available at https://heinonline.org/HOL/LandingPage?handle=hein.journals/udetmr35\&div=45\&id=\&page=.

${ }^{1}$ Ibid.

${ }^{1}$ See Id. (citing California is the only state whose statute cannot be traced to some other model. See CAL. COP. CODE $\S \S$

\footnotetext{
${ }^{1}$ See D.R Ulrike Glueck, Penny Li, "PRC Peoples Supreme Court Issued Provision on Several Issues Concerning the Application of The Company Law of The Peoples Republic China(v)" available at https://www.lexology.com/library/detail.aspx?g=741ecfa9-a3c4-4f30-aed2ecae3301a00a.

${ }^{2}$ See ibid.

3 See https://cms.law/en/CHN/Publication/PRC-Supreme-People-s-Court-issued-Provisions-on-Several-Issues-Concerning-the-Applicationof-the-Company-Law-of-the-People-s-Republic-of-China-V.

${ }^{4}$ See PRC Supreme People's Court Published Interpretation V of The Company Law available at https:/www.burenlegal.com/en/news/prcsupreme-peoples-court-published-interpretation-v-company-law.

${ }^{5}$ See http:/www.ghiplegal.com/laws/company.html.

${ }^{6}$ See Frank T. Gallo, "Business Leadership in China: How to Blend Best Western Practices with Chinese Wisdom" (2008).
} 
2230-31 (1955)

${ }^{1}$ See Id. (citing The text of these laws and models appears in Appendices A-1 to A-5.

${ }^{1}$ See Carl Martin Ross, "Comparative Note on Shareholders Voting Agreement", 15 SCANDinavian Studies IN LAW, 163-190 (1971) available at https://heinonline.org/HOL/Page?handle=hein.intyb/svns10015\&id=163\&collection=intyb\&index=.

${ }^{1}$ See Gianfranco Gianfrate What Do Shareholders Coalition Really Want? Evidence From Italian Voting Trusts (2007) Corporate Governance An: International Review V.15 Iss.2 pp.122-132 available at https://onlinelibrary.wiley.com/doi/full/10.1111/j.1467-8683.2007.00549.x.

${ }^{1}$ See ibid (citing Volpin (2002).

${ }^{1}$ See Section 59 of the Corporation Code of The Philippines provides for the establishment of a voting trust agreement not exceeding five years duration.

1 See "Trust-Type Rights Plan", Trust Companies Association of Japan (2020) available at https://www.shintakukyokai.or.jp/en/trusts/trusts03_14_10.html.

1 See Maurice Finkelstein, Voting Trust Agreements, 24 Mich. L. Rev. $344 \quad$ (1926) available at https://heinonline.org/HOL/Page?collection=journals\&handle=hein.journals/mlr24\&id=373\&men tab=srchresults\#.

${ }^{1}$ Ibid.

${ }^{1}$ Ibid.

${ }^{1}$ Ibid.

${ }^{1}$ Ibid.

${ }^{1}$ Ibid.

1 See "The Voting Trust: Drafting Suggestions", 42 N.Y.U. L. Rev. 349 (1967) available at https://heinonline.org/HOL/Page?collection=journals\&handle=hein.journals/nylr42\&id=380\&men_tab=srchresults.

${ }^{1}$ Ibid.

${ }^{1}$ Ibid

${ }^{1}$ Ibid.

${ }^{1}$ Ibid.

1 See John J. Woloszyn, "A Practical Guide to Voting Trusts," U. of Baltimore L. ReV.: Vol. 4: Iss. 2, Article 4 (1975) available at: http://scholarworks.law.ubalt.edu/ublr/vol4/iss2/4.

1 See Louie M. Horne, Voting Trust Agreements in Indiana, 19 IND. L.J. 225, 226 (1944) available at https://heinonline.org/HOL/Page?collection=journals\&handle=hein.journals/indana19\&id=236\&men_tab=srchresults\# ${ }^{1}$ Ibid. (citing 60 N.J.Eq. 79,47 Atl. 345 (1900).

1 Ibid (citing Frost v. Carse, 91 N.J.Eq. 124, 108 Atl. 642 (1919).

${ }^{1}$ See ibid; Turner Vann Adams, "Corporations -- Voting Trusts -- Should Trust Principles Apply to Close Corporations?", 48 N.C. L. REv. 336, 344 (1970).

${ }^{1}$ See Maria Goranova, Lori Verstegen Ryan Shareholder Activism: A Multidisciplinary Review Journal of Management 2013 available at http://jom.sagepub.com/content/early/2013/12/13/0149206313515519 (citing (David, Bloom, \& Hillman, 2007; David, Hitt, \& Gimeno, 2001, Song \& Szewczyk, 2003; Westphal \& Bednar, 2008).

${ }^{1}$ See ibid (citing (Davis \& Thompson, 1994; Dimitrov \& Jain, 2011).

${ }^{1}$ See ibid (citing (Clark \& Crawford, 2012; David et al., 2007; Reid \& Toffel, 2009).

${ }^{1}$ See ibid (citing (Karpoff, Malatesta, \& Walkling, 1996; Wahal, 1996).

${ }^{1}$ See ibid (citing Duhigg, 2007: C1)

${ }^{1}$ See ibid (citing Davis \& Thompson, 1994; Kahan \& Rock, 2010).

${ }^{1}$ See Marco Becht, Julian Franks, Colin Mayer, Stefano Rossi, "Returns to Shareholder Activism Evidence from a Clinical Study of the Hermes U.K. Focus Fund" (2007) available at https://www.academia.edu/people/search?utf8=\%E2\%9C\%93\&q=shareholder+activism+disadvantage

${ }^{1}$ See Janet H. Marler, Christophe Faugère, "Shareholder Activism and Middle Management Equity Incentives", Corporate Governance: An International Review, 2010, 18(4): 313-328 (citing Ryan \& Schneider, 2002; Parrino et al., 2003).

${ }^{1}$ See ibid.

1 See Donald Nordberg, "Some Are More Equal: The Politics of Shareholder Activism" (2009) available at http://dx.doi.org/10.2139/ssrn.1150130.

${ }^{1}$ See supra $\mathrm{n} .2$.

${ }^{1}$ See ibid.

${ }^{1}$ See Gerald R. Thompson, Chapter 3: The Characteristics of Law, Legal Foundations: The Framework of Law, LONANG INSTITUTE (2010) available at https://lonang.com/commentaries/foundation/framework-of-law/text/the-characteristics-oflaw/.

${ }^{1}$ See Dr. Zhao Ying, "A Brief Guide to The Legal System of China", DAILY FT (June 21, 2018) available at $\mathrm{http}: / /$ www.ft.lk/columns/A-brief-guide-to-the-legal-system-of-China/4-657550.

${ }^{1}$ See https://www.jus.uio.no/lm/china.company.law.1993/.

${ }^{1}$ See ibid.

${ }^{1}$ See Ignazio Castellucci, "Rule of Law with Chinese Characteristics," Annual Survey of Int'l \& Comp. L.: Vol. 13, Iss. 1, Article 4, p. 38 (2007), available at http://digitalcommons.law.ggu.edu/annlsurvey/vol13/iss1/4.

${ }^{1}$ Ibid at 46 .

${ }^{1}$ See Mo Zhang, "The Socialist Legal System with Chinese Characteristics: China's Discourse for the Rule of Law and Bitter Experience”, 24.1 TEMPLE INT’L \& COMP. L. J. 1, 44 (2010).

${ }^{1}$ Ibid at 48

1 See Milton M. Bergerman, "Voting Trust and Non-Voting Stock" YALE L. J. 445, 454 available at 
https://digitalcommons.law.yale.edu/cgi/viewcontent.cgi?referer=\&httpsredir=1\&article=3268\&context=ylj.

${ }_{1}^{1}$ See Carl Martin Ross, supra n.10.

1 See Company Law of the People's Republic of China (2018 Revision) available at http://www.ghiplegal.com/static/frontend/img/pdf/company_law_en.pdf.

${ }^{1}$ See Gary D. Burger, "The Voting Trust: California Effects A Barrier To A Rationale Law of A Corporate Control", STANFORD L. $\quad$ REV. 18(6) 1210, 1210-1220 (1966) available https:/www.jstor.org/stable/1227129?Search=yes\&resultItemClick=true\&searchText=voting\&searchText=trust\&search $\mathrm{Text}=\mathrm{impact} \&$ searchText $=$ on\&searchText $=$ minority\&searchText $=$ shareholder\&searchUri $=\% 2 \mathrm{Faction} \% 2 \mathrm{FdoBasicSearc}$ $\mathrm{h} \% 3 \mathrm{FQuery} \% 3 \mathrm{Dvoting} \% 2 \mathrm{Btrust} \% 2 \mathrm{Bimpact} \% 2 \mathrm{Bon} \% 2 \mathrm{Bminority} \% 2 \mathrm{Bshareholder} \% 26 \mathrm{amp} \% 3 \mathrm{Bfilter} \% 3 \mathrm{D} \& \mathrm{ab}$ segment $\mathrm{s}=0 \% 2 \mathrm{Fl} 2 \mathrm{~b} \_100 \mathrm{k} \_$with_tbsub$\% 2 \mathrm{~F}$ control\&seq=1\#metadata_info_tab_contents.

${ }^{1}$ Ibid.

${ }^{1}$ Ibid.

${ }^{1}$ Ibid.

${ }^{1}$ See ibid.

${ }^{1}$ See Zhihong Chang, Bin Ke, Zhifeng Yang, "Minority Shareholders Control Right and The Quality of Corporate Decisions In The Weak Investor Protection Countries: A Natural Experiment From China," The Accounting Rev., Vol .88, No. 4, 1211 1212 (2013) available

at https:/www.jstor.org/stable/23525976?Search=yes\&resultItemClick=true\&searchText=voting\&searchText=trust\&searc $\mathrm{hText}=\mathrm{impact} \& \operatorname{searchText}=$ on\&searchText $=$ minority\&searchText $=$ shareholder\&searchUri $=\% 2 \mathrm{Faction} \% 2 \mathrm{FdoBasicSear}$ ch\%3FQuery\%3Dvoting\%2Btrust\%2Bimpact\%2Bon\%2Bminority\%2Bshareholder\%26amp\%3Bfilter\%3D\&ab_segmen ts $=0 \% 2 \mathrm{~F} 12 \mathrm{~b} \_100 \mathrm{k}$ _with_tbsub $\% 2 \mathrm{~F}$ control\&refreqid=search $\% 3 \mathrm{~A} 934 \mathrm{ab} 6 \mathrm{be} 73 \mathrm{acdca} 2113362401 \mathrm{de} 0 \mathrm{~d} 9 \mathrm{c} 8 \&$ seq $=1 \#$ metada ta_info_tab_contents.

1 See generally, ibid.

${ }^{1}$ For example, the UK Companies Act provides protection for minority shareholders, as well as laws in other parts of Europe, Japan, and India. See Section 994 of the Companies Act 2006 (United Kingdom); IOSCO, "Protection of Minority Shareholders in Listed Issuers" (June 2009) available at https://www.iosco.org/library/pubdocs/pdf/IOSCOPD295.pdf; Sections 397 to 409 of the Companies Act of India 1956 (Companies Act).

1 See Shan Yuxiao, Denise Jia, "Supreme Court Move to Protect Minority Holders Rights" (2019) available at https://www.caixinglobal.com/2019-04-30/supreme-court-moves-to-protect-minority-holder-rights-101410188.html.

${ }^{1}$ See D.R Ulrike Glueck, Penny Li, "PRC Peoples Supreme Court Issued Provision on Several Issues Concerning the Application of The Company Law of The Peoples Republic China(v)" available at https://www.lexology.com/library/detail.aspx?g=741ecfa9-a3c4-4f30-aed2-ecae3301a00a.

${ }^{1}$ See ibid.

1 See https://cms.law/en/CHN/Publication/PRC-Supreme-People-s-Court-issued-Provisions-on-Several-Issues-Concerningthe-Application-of-the-Company-Law-of-the-People-s-Republic-of-China-V.

1 See PRC Supreme People's Court Published Interpretation V of The Company Law available at https://www.burenlegal.com/en/news/prc-supreme-peoples-court-published-interpretation-v-company-law.

${ }^{1}$ See http://www.ghiplegal.com/laws/company.html.

${ }^{1}$ See Frank T. Gallo, "Business Leadership in China: How to Blend Best Western Practices with Chinese Wisdom" (2008). 